
$\frac{197}{12-9-86 \text { st (1) } \frac{5-40}{N-15}} \frac{10}{T 1-55}$
OR $0051-5$
I- 25857

MLM-3395

General Purpose Heat Source (GPHS) Clad Vent Set (CVS) Formability Study

Mary A. Forrest, James R. McDougal, and

Ranny W. Saylor

November 3, 1986

$$
\begin{aligned}
& \text { DO NOT MICROFILA } \\
& \text { COVER }
\end{aligned}
$$

MOUND

Miamisburg. Ohio 45342

operated by

MONSANTO RESEARCH CORPORATION

a subsidiary of Monsanto Company

for the

U. S. DEPARTMENT OF ENERGY

Contract No.DE-ACO4-76-DPODO53 


\section{DISCLAIMER}

This report was prepared as an account of work sponsored by an agency of the United States Government. Neither the United States Government nor any agency Thereof, nor any of their employees, makes any warranty, express or implied, or assumes any legal liability or responsibility for the accuracy, completeness, or usefulness of any information, apparatus, product, or process disclosed, or represents that its use would not infringe privately owned rights. Reference herein to any specific commercial product, process, or service by trade name, trademark, manufacturer, or otherwise does not necessarily constitute or imply its endorsement, recommendation, or favoring by the United States Government or any agency thereof. The views and opinions of authors expressed herein do not necessarily state or reflect those of the United States Government or any agency thereof. 


\section{DISCLAIMER}

Portions of this document may be illegible in electronic image products. Images are produced from the best available original document. 


\section{DISCLAIMER}

Thus report was prepared as an account of work sponsored by an agency of the United States Covernment. Neither the United States Government nor any agency thereof, nor any of their employees, makes any warranty, express or implied, or assumes any legal liabil.ty or responsibility for the accuracy, completeness, or usefulness of any information, apparatus, product, or process disclosed, or represents that its use would not infringe privately owned rights. Reference herein to any specific commercial product, process, or service by trade name, trademark, manufacturer, or otherwise, does not necessarily constitute or imply its endorsement, recommendation, or favoring by the United States Government or any agency thereof. The views and opinions of authors expressed herein do not necessanly state or reflect those of the United States Government or any agency thereof.

Printed in the United States of America

Available from

National Technical Information Service

U.S. Department of Commerce

5285 Port Royal Road

Springfield, VA 22161

NTIS price codes

Printed Copy: $\mathrm{AO2}$

Microfiche copy: $\mathrm{A01}$

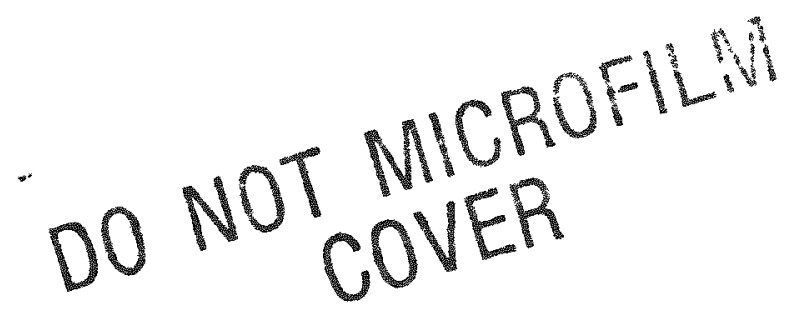


Operated for the United States

Department of Energy

December 4, 1986

MLM- -3395

DE87 002682

TO: Distribution

\section{E R R A T A}

The following "pen and ink" change should be made to MLM-3395, General Purpose Heat Source (GPHS) Clad Vent Set (CVS) Formability Study, 3 November 1986:

Page 13, Observation No. 5, under "Recommendation" change $600^{\circ} \mathrm{C}$ to $1000^{\circ} \mathrm{C}$.

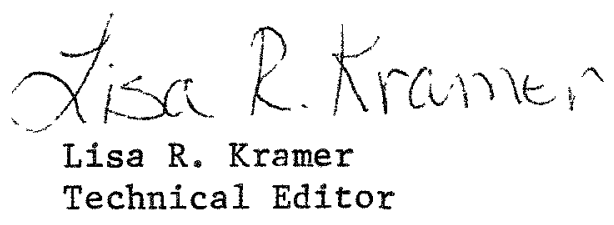




\title{
General Purpose Heat Source (GPHS)
Clad Vent Set (CVS) Formability Study
}

\author{
Mary A. Forrest, James R. McDougal, and \\ Ranny W. Saylor
}

Issued: November 3, 1986

\section{DISCLAIMER}

\begin{abstract}
This report was prepared as an account of work sponsored by an agency of the United States Government. Neither the United States Government nor any agency thereof, nor any of their employees, makes any warranty, express or implied, or assumes any legal liability or responsibility for the accuracy, completeness, or usefulness of any information, apparatus, product, or process disclosed, or represents that its use would not infringe privately owned rights. Reference herein to any specific commercial product, process, or service by trade name, trademark, manufacturer, or otherwise does not necessarily constitute or imply its endorsement, recommendation, or favoring by the United States Government or any agency thereof. The views and opinions of authors expressed herein do not necessarily state or reflect those of the United States Government or any agency thereof.
\end{abstract}

\footnotetext{
MOUND

Miamisburg. Onio 45342

operated by

MONSANTO RESEARCH CORPORATION
a subsidiary of Monsanto COMPany
for the

U. S. DEPARTMENT OF ENERGY

Contract No DE-ACO4-7E-DPOOO53
} 


\section{Contents}

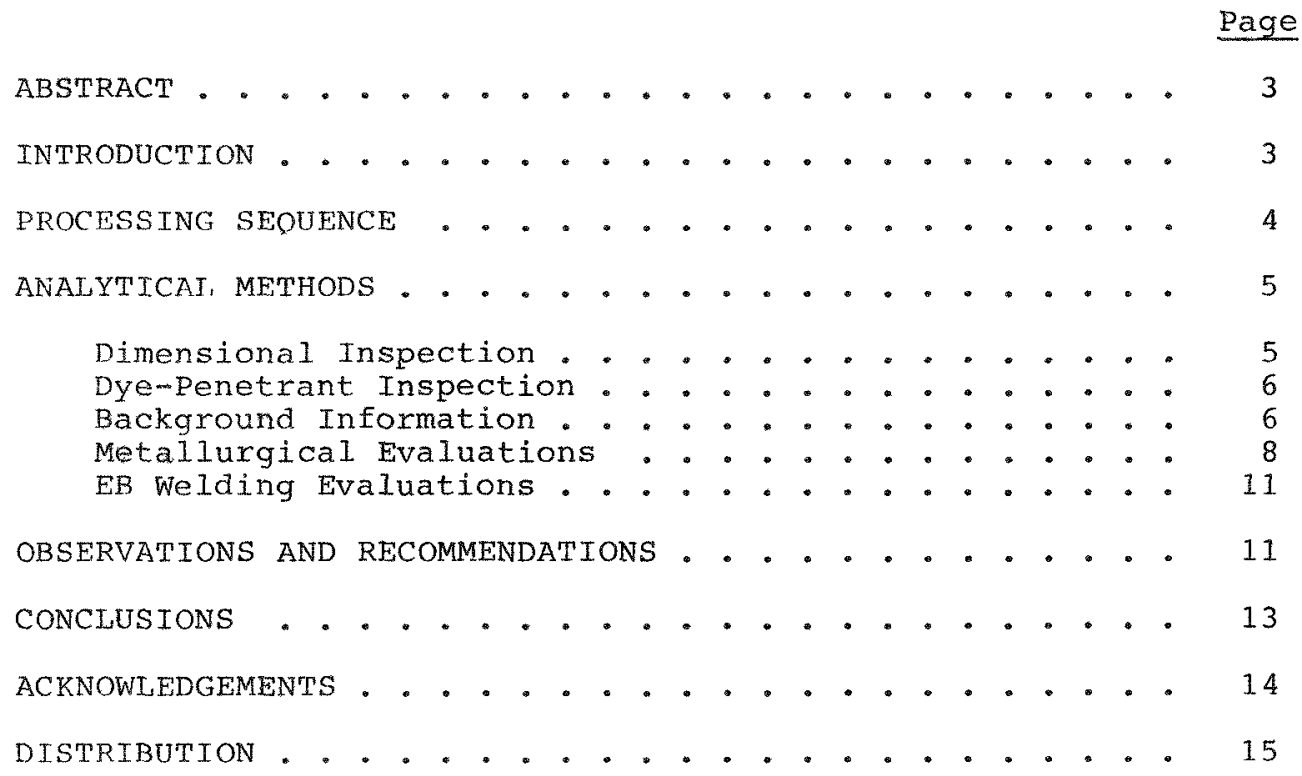




\begin{abstract}
Monsanto Research Corporation/Mound completed a general purpose heat source (GPHS) clad vent set (CVS) formability study in support of phase I objectives of Oak Ridge National Laboratory's (ORNL) "Technical Plan for Qualification of Improved Iridium DoP-26 Alloy Fabrication Process."

Primarily, Mound was to evaluate both improved-iridium and standardflight iridium blanks with respect to current GPHS-CVS manufacturing processes and provide example-weld-quality CVS to the Savannah River Plant (SRP) for its weldability study. Additionally, Mound's practice of performing a final outgassing $\left(1500^{\circ} \mathrm{C}\right.$ for $\left.1 \mathrm{hr}\right)$ of CVs was evaluated with respect to metallurgical properties of iridium cups and electron-beam (EB) welding characteristics of CVS subassembly components.
\end{abstract}

The only significant problem encountered was wall thickness variation, which will cause a welding problem at SRP. This anomaly may be corrected by mechanical grinding; however, additional forming studies will be performed using stress-relieved blanks to see if this corrects the problem.

Improved iridium did not meet microhardness requirements when subjected to the $1500^{\circ} \mathrm{C}$ outgassing temperature. In addition, it failed to fully recrystallize when exposed to the $1300^{\circ} \mathrm{C}$ recrystalization temperature. The preliminary examination of $\mathrm{EB}$ welding characteristics showed no cvs manufacturing problems with ORNL's proposed fabrication process or Mound's suggestion to change the final outgassing temperature to $1000^{\circ} \mathrm{C}$. This parameter is well below the recrystallization temperature and would assure product cleanliness for subsequent $\mathrm{EB}$ welding operations.

Based on a relatively small sample size, the data generated to date strongly support the continuation of ORNL's development plan. Mound suggests that the recommended changes defined in this document be further evaluated in phase II and phase III of ORNL's study.

\section{Introduction}

Monsanto Research Corporation/Mound completed a general purpose heat source (GPHS) clad vent set (CVS) formability study in support of phase I objectives of Oak Ridge National Laboratory's (ORNL) "Technical Plan for Qualification of Improved Tridium DOP-26 Alloy Fabrication
Process." ORNL is investigating an improved production process for fabricating iridium blanks and foil for heat sources that use the GPHS-designed iridium CVS hardware components. This fabrication method, referred to as improved iridium, uses a consumable arc-melted large ingot, which is extruded into the bar form for 
subsequent rolling into sheet material. The previous method, referred to as standard-flight iridium, used small arcmelted and drop-cast ingots. The new fabrication method eliminated shrinkage cavities and porosity in the iridium ingot and, when used with a higher degree of warm-working and a revised rolling schedule, yielded a more uniform grain structure in the finished sheet material. The ORNL objective of reducing the ultrasonic defect-indication rejection rate from $30 \%$ to $15 \%$ was realized when this rate went below 58 in a developmental lot of $B$-batch improved-iridium blanks.

The purpose of Mound's formability study was twofold. Primarily, Mound was to evaluate both improved-iridium and standard-flight iridium blanks with respect to current GPHS-CVS manufacturing processes and provide example-weld-quality CVS to the Savannah River Plant (SRP) in support of its weldability study. Additionally, Mound's practice of performing a final outgassing $\left(1500^{\circ} \mathrm{C}\right.$ for $\left.1 \mathrm{hr}\right)$ of CVS was evaluated with respect to metallurgical properties of iridium cups and electron-beam (EB) welding characteristics of CVS subassembly components. This document details Mound's processing sequence, analytical methods, observations, recommendations, and conclusions.

\section{Processing Sequence}

Twenty-four improved and 10 standardflight iridium blanks were processed in accordance with Mound's technical manual. MD-70220, "General Purpose Heat Source." However, only the steps necessary to manufacture example-weld-quality iridium cups were completed. Exceptions to MD-70220, Operation 1, Manufacture of Iridium Cups (Issue 11), are noted as follows:
1. Suboperation 2 - Scribe Blanks: The $0.01 \mathrm{~mm}$ maximum depth was not verified because depth would not affect weldability characteristics.

2. Suboperation 13 - Dye-Penetrant Inspection: The iridium blanks were cleaned and dye-penetrant inspected prior to Mound's forming operations to verify correlation between Mound's and ORNL's inspection methods.

3. Suboperation 16 - Vent Notch: The vent notch feature was not required to support SRP's weldability study. However, a laser-marked orientation feature was added to help SRP identify the original weld-overlap area.

4. Suboperation 17 - E.D.M. Vent Hole: This operation was performed on all iridium cups to facilitate Mound's subsequent matching of CVS.

5. Suboperation 19 - Grit Blast: This operation was not performed because the grit-blasted surface is not normally applied in the weld-zone area of CVS. This surface could have been detrimental to SRP's weldability study. Therefore, suboperation 18 (Cleaning the Cups) was also deleted in Mound's formability study.

6. Suboperation 20 - Final Inspection: A $100 \%$ dimensional inspection was performed on all weld-zone attributes, and the remaining attributes were sampled on a $25 \%$ frequency. The diameter and location of the vent holes were not verified.

7. Suboperation 23 - Outgas: The 1-hr final outgassing at $1500^{\circ} \mathrm{C}$ was not performed on a selected population of iridium cups. 
Mound's formability study used the same processing equipment and fixturing that was used to produce "flight-quality" GPHS CVS for the Galileo and Ulysses programs. Also, warm-forming support materials (tantalum barrier discs, stainless steel waster sheets, and mild-steel compensation cups) were stockpiled items remaining from the GPHS production run. Critical operations, such as EB welding of discs into waster sheets, warm-forming (first and second draw), trim-to-length procedures, precharging, sizing, and lap-to-length procedures, were performed by experienced personnel.

QC engineering personnel oversaw the warm-forming operations on the improved iridium and recorded the temperature parameters for iridium blanks and tooling (Table 1). The temperature parameters were held reasonably constant and well within specification limits.

\section{Analytical Methods}

\section{Dimensional Inspection}

Mound's Quality Control Inspection group performed a $100 \%$ dimensional inspection of weld-zone attributes $129.88 / 29.73 \mathrm{~mm}$ outside diameter, $15.12 / 15.04 \mathrm{~mm}$ outside length, $0.73 / 0.63 \mathrm{~mm}$ wall thickness, $0.08 \mathrm{~mm}$ roundness, $0.013 \mathrm{~mm}$ flatness, and $0.05 \mathrm{~mm}$ maximum outside edge break). Mound randomly sampled 25 응 of the iridium cups for the remaining attributes $129.82 /$ $26.60 \mathrm{~mm}$ outside diameter, $0.55 \mathrm{~mm}$ minimum wall thickness, and $5.96 / 5.68 \mathrm{~mm}$ outside radius). The $0.51 / 0.38 \mathrm{~mm}$ vent hole diameter and location were not critical to SRP's weldability study and were not inspected. AII product drawing requirements were met except for the $0.73 / 0.63 \mathrm{~mm}$ wall thickness at the open-end (weld zone) of the iridium cup. The 22 improved-iridium cups (two dyepenetrant rejected cups were not subjected to dimensional inspection) and eight of the 10 standard-flight iridium cups exceeded the limit in this area. In all cases, the weld-zone wall was too thick to meet design specifications. The average wall thickness variation within each iridium cup was $0.079 \mathrm{~mm}$ and $0.062 \mathrm{~mm}$ for the improved and standardflight iridium, respectively. However, $72.7 \%$ of the improved-iridium cups experienced a wall thickness variation greater than $0.05 \mathrm{~mm}$ (two mils), compared to 50.08 of the standard-flight iridium cups. The loss of dimensional control of this attribute is believed to be attributable to forming characteristics associated with B-batch iridium powder. The archive rings lexcess material removed in Mound's trim-to-length operation) were considerably shorter than GPHS production units and displayed pronounced lobed areas (Figures 1, 2, and 3 ).

Table 1 - STATISTICAL ANALYSIS OF IRIDIUM WARM-FORMING OPERATIONS

\begin{tabular}{|c|c|c|c|c|c|c|}
\hline Operation & & $\begin{array}{c}\text { Specification } \\
\left({ }^{\circ} \mathrm{C}\right)\end{array}$ & Mean & $\begin{array}{l}\text { Standard } \\
\text { Deviation } \\
\end{array}$ & Variation & $\begin{array}{c}\text {-3 sigma } \\
\text { Iimits } \\
\end{array}$ \\
\hline 1st Draw & $\begin{array}{l}\text { Furnace } \\
\text { Punch } \\
\text { Die }\end{array}$ & $\begin{array}{l}900 / 950 \\
225 / 275 \\
225 / 275\end{array}$ & $\begin{array}{l}926.0 \\
250.0 \\
249.2\end{array}$ & $\begin{array}{l}4.58 \\
6.23 \\
6.80\end{array}$ & $\begin{array}{l}21.04 \\
38.91 \\
46.26\end{array}$ & $\begin{array}{l}912.3 \\
231.3 \\
228.8\end{array}$ \\
\hline 2nd Draw & $\begin{array}{l}\text { Furnace } \\
\text { Punch } \\
\text { Die }\end{array}$ & $\begin{array}{l}900 / 950 \\
225 / 275 \\
225 / 275\end{array}$ & $\begin{array}{l}928.1 \\
251.1 \\
250.5\end{array}$ & $\begin{array}{l}3.18 \\
2.76 \\
3.93\end{array}$ & $\begin{array}{r}10.11 \\
7.69 \\
3.93\end{array}$ & $\begin{array}{l}918.6 \\
242.9 \\
238.7\end{array}$ \\
\hline
\end{tabular}




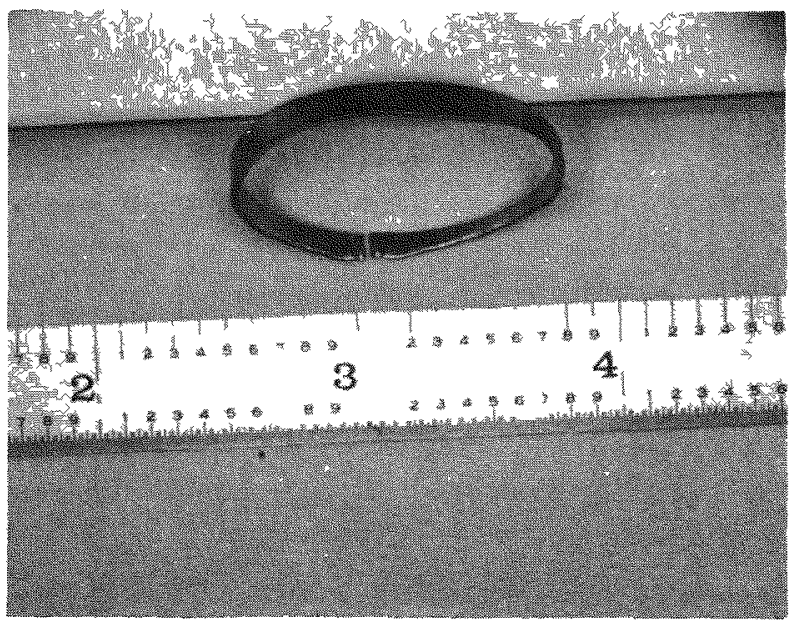

IIGURE 1 - Archive ring YR423-3. Typical archive ring from GPHS production. Note cracked area associated with "identity" notches in iridium blank.

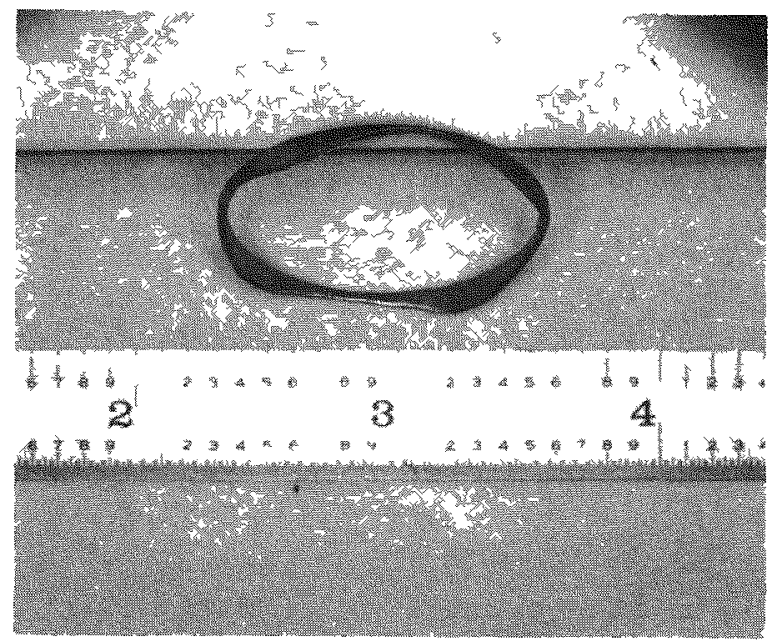

FIGURE 3 - Archive ring B1-2-3 from improved-iridium formability study. Pronounced lobed areas in four quadrants were observed.

\section{Dye-Penetrant Inspection}

Al1 34 of the as-formed iridium cups were free of dye-penetrant detectable surface cracks in the cup sidewall (outside) and radius areas. This condition had been a persistent problem in Mound's GPHS production run and was corrected by implementing a mechanical polishing

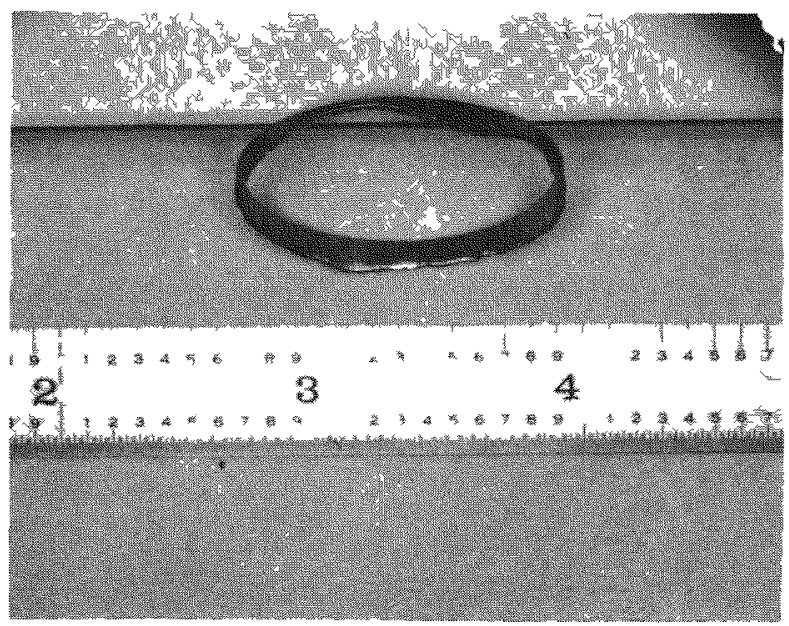

FIGURE 2 - Archive ring B729-3. Archive ring from standard-flight iridium. Lobed areas were observed in two quadrants.

procedure to remove surface imperfections less than $1 \mathrm{mil}$ deep. Dye-penetrant inspection following the lap-to-length operation revealed that two improvediridium cups were cracked across the open-end face, but none of the 34 lapped cups experienced delaminations in the machined/lapped surface.

\section{Background Information}

The occurrence of sidewall cracks is associated with ORNL's identity notches ground along the edge of the irldium blanks. These notches caused wrinkling (Figure 4) and cracking (Figure 5) during Mound's iridium cup warm-forming processes. Sidewall delaminations (Figure 6) first appeared in Mound's GPHS production lot $\mathrm{P}-30$. Most of the delaminations were located $90^{\circ}$ from ORNL's rolling direction and were within the inner third of the iridium cup wall thickness. This area parallel to the rolling direction consisted of elongated grains and appeared to be the most susceptible location for delamination. 


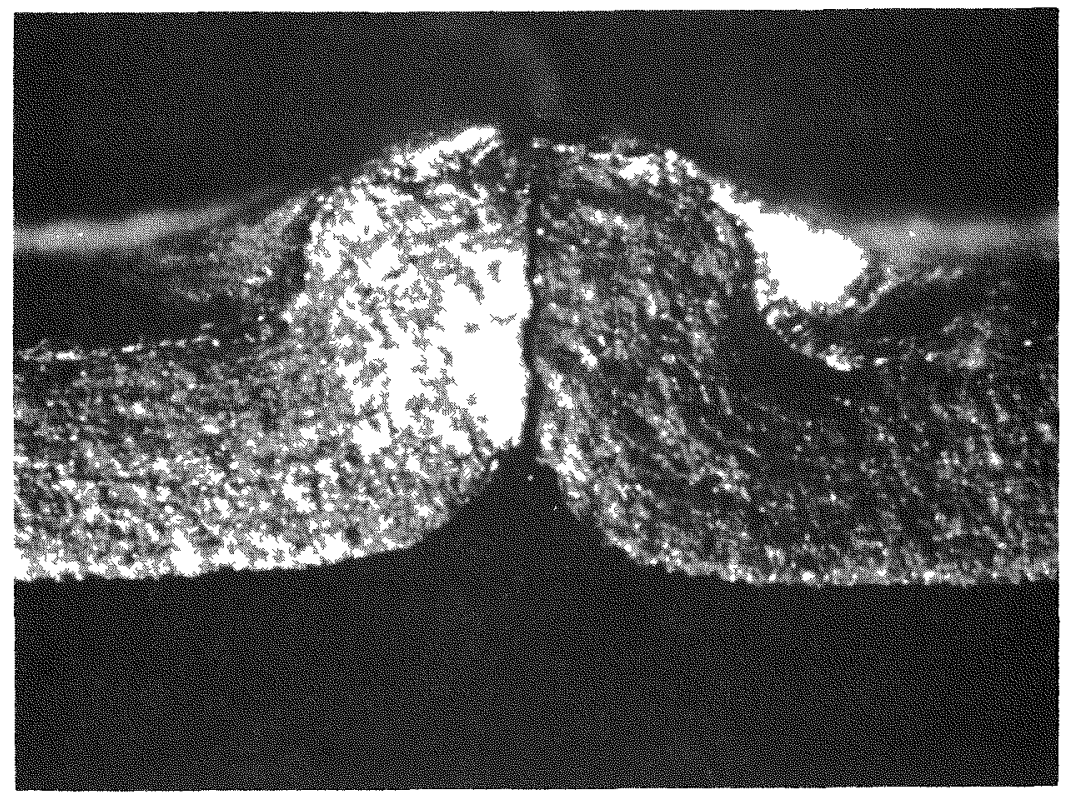

FIGURE 4 - Archive ring SR050-6 (20X). Wrinkled area at the open-end of iridium cup resulting from "identity" notches in iridium blanks.

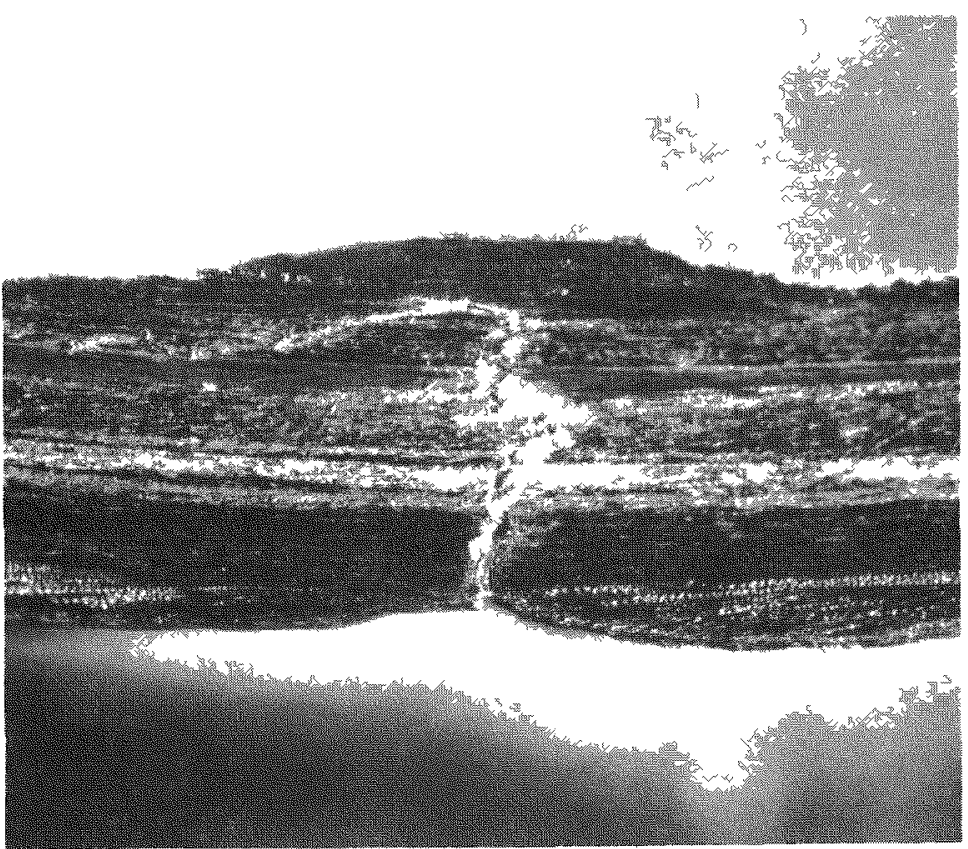

FIGURE 5 - Archive ring SR050-6 (20X). Cracked area in archive ring which propagated into iridium cup. 


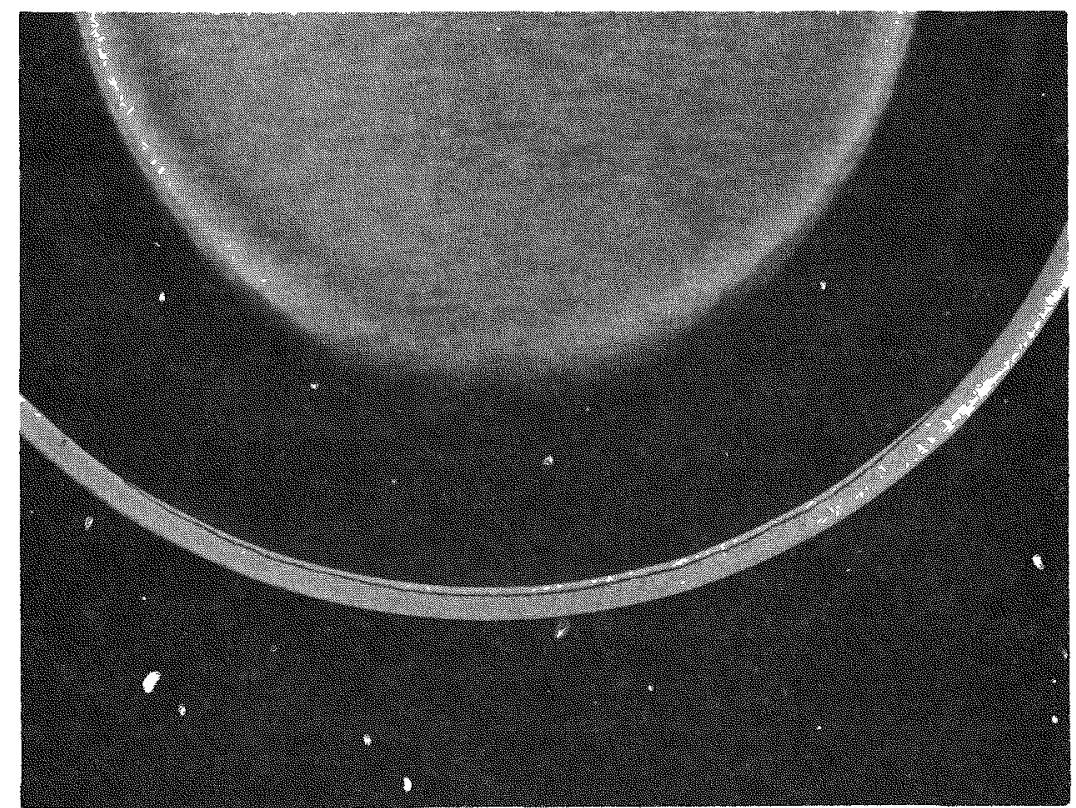

FIGURE 6 - Iridium cup S034-1 (5X). Delaminated areas occurred predominantly $90^{\circ}$ from rolling direction as indicated by ground surfaces.

Cracked/delaminated and dye-penetrant rejected iridium cups accounted for the majority $(98.7 \%)$ of the "less-than-prime" iridium hardware fabricated in GPHS production lots $\mathrm{P}-30$ through $\mathrm{P}-50$. Mound's production yields, listed in Table 2, averaged $75.0 \%$ prime cups, $2.6 \%$ analytical samples, $22.1 \%$ dye/visual rejects, and $0.3 \%$ other (dimensional rejects, etc.). Although the prime yield fluctuated from group to group (Figure 7), this problem could not be correlated to the techniques or materials used by Mound or ORNL.

\section{Metallurgical Evaluations}

Three of the iridium cups from Mound's formability study were selected as analytical samples for verification of metallurgical properties defined per Mound's product specification SPA-790433, Specification for Deep Drawn Iridium Cups
(Issue E). Iridium cups B2-1-3 (improved/ outgassed). BI-1-4 (improved/not outgassed), and B732-6 (standard-flight/ outgassed) were subjected to tests specified in paragraphs 3.2 .1 (Hardness) and 3.2 .2 (Microstructure). The microhardness values listed in Table 3 averaged 286 to 366 diamond pyramid hardness (DPH) for improved iridium/ outgassed, 306 to 391 DPH for improved iridium/not outgassed, and 251 to $337 \mathrm{DPH}$ for standard-flight/outgassed. Both analytical samples from the improved iridium displayed microhardness greater than the specification limit of 250 to $350 \mathrm{DPH}$. Also, the improved iridium material that was not subjected to the final outgassing temperature of $1500^{\circ} \mathrm{C}$ was not fully recrystallized (Figure 8). Grain size on all three analytical samples was ASTM $7 \quad 14: 1$ elongation ratiol, and no inclusions, second phase 
Table 2 - IRIDIUM CUP PROCESS YIELDS (P-30 THROUGH P-50)

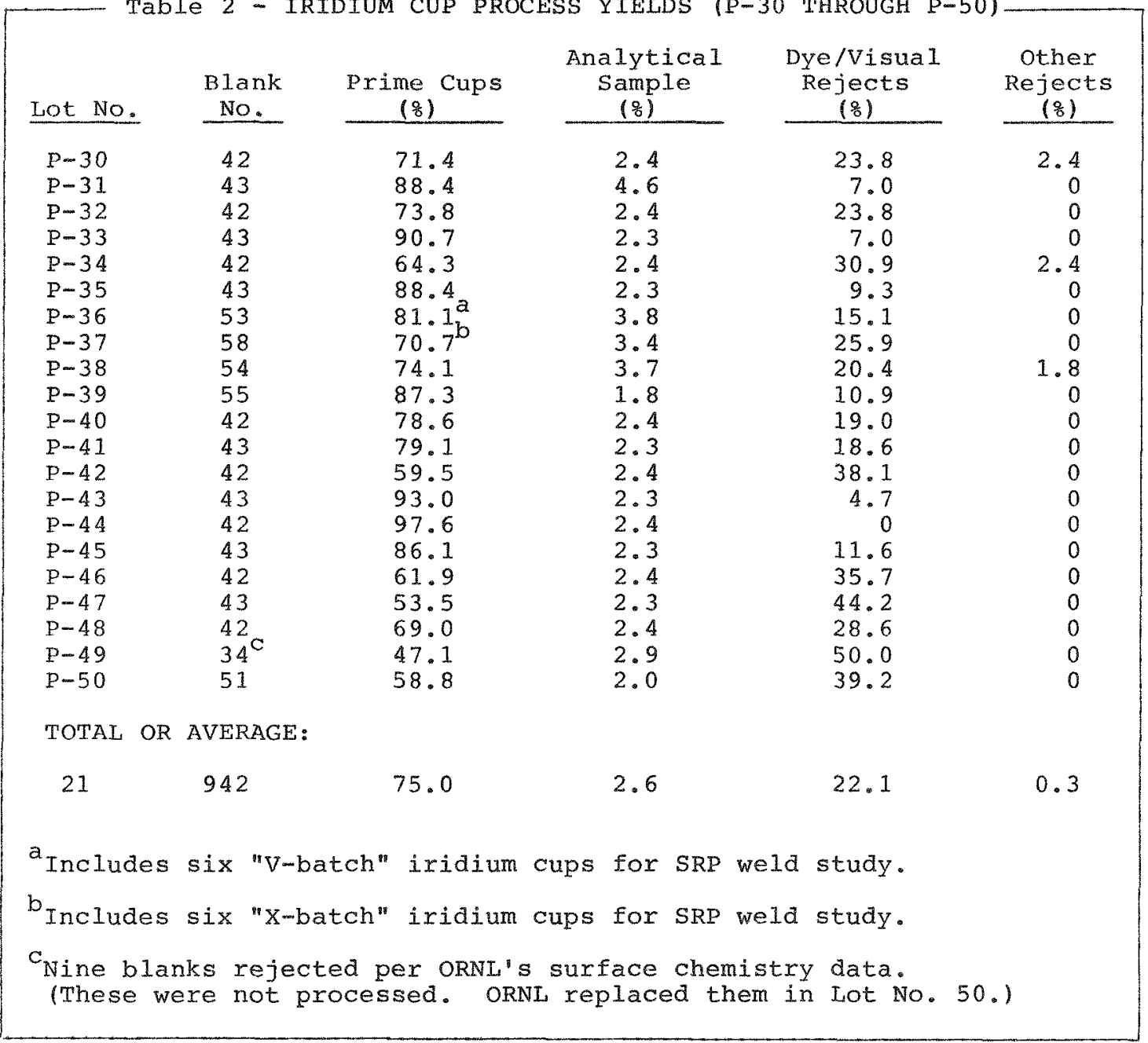

PERCENT PRTME CUPS

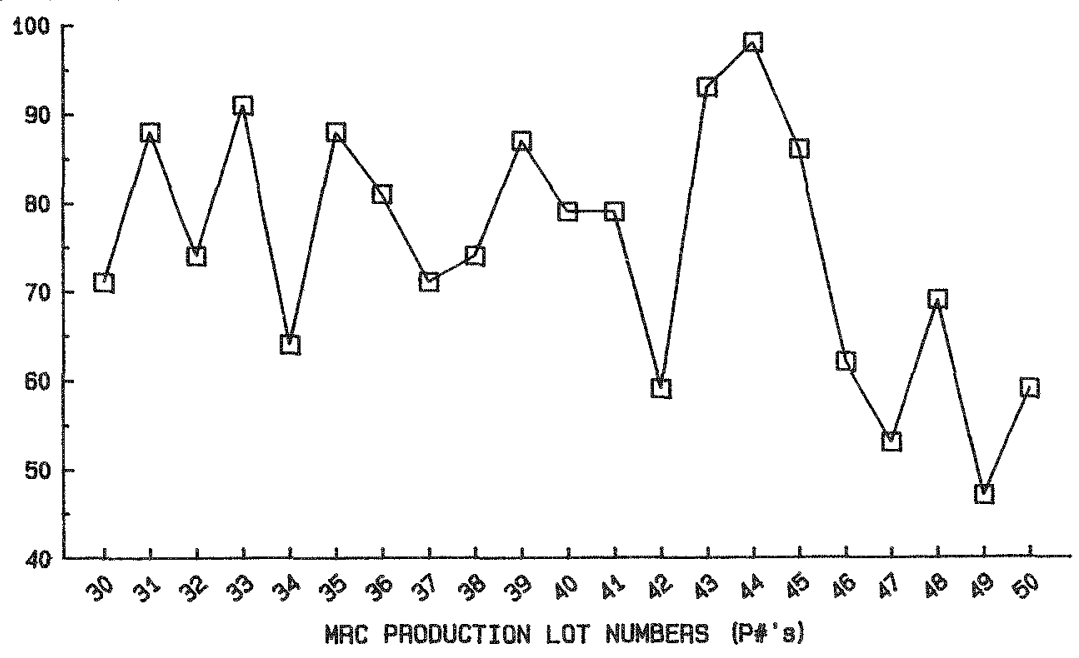

FIGURE 7 - Iridium cup prime yields $(P-30$ through $P-50)$. 
Table 3 - MICROHARDNESS VALUES

\begin{tabular}{|c|c|c|c|c|c|}
\hline Cup No. & $\begin{array}{l}\text { Sample } \\
\text { No. }\end{array}$ & Location & Bottom DPH & Radius DPH & End DPH \\
\hline \multirow[t]{2}{*}{ B732-6 } & 3 & $\begin{array}{l}\text { Inside Edge } \\
\text { Center } \\
\text { Outside Edge } \\
\text { Average }\end{array}$ & $\begin{array}{l}210 \\
257 \\
286 \\
251\end{array}$ & $\begin{array}{l}341 \\
341 \\
330 \\
337\end{array}$ & $\begin{array}{l}303 \\
264 \\
312 \\
293\end{array}$ \\
\hline & 6 & $\begin{array}{l}\text { Inside Edge } \\
\text { Center } \\
\text { Outside Edge } \\
\text { Average }\end{array}$ & $\begin{array}{l}264 \\
278 \\
286 \\
276\end{array}$ & $\begin{array}{l}286 \\
264 \\
278 \\
276\end{array}$ & $\begin{array}{l}278 \\
278 \\
341 \\
299\end{array}$ \\
\hline \multirow[t]{2}{*}{ B2-1-3 } & 3 & $\begin{array}{l}\text { Inside Edge } \\
\text { Center } \\
\text { Outside Edge } \\
\text { Average }\end{array}$ & $\begin{array}{l}294 \\
321 \\
303 \\
306\end{array}$ & $\begin{array}{l}312 \\
278 \\
278 \\
289\end{array}$ & $\begin{array}{l}374 \\
374 \\
\frac{351}{366} \mathrm{a}\end{array}$ \\
\hline & 6 & $\begin{array}{l}\text { Inside Edge } \\
\text { Center } \\
\text { Outside Edge } \\
\text { Average }\end{array}$ & $\begin{array}{l}278 \\
286 \\
294 \\
286\end{array}$ & $\begin{array}{l}341 \\
321 \\
341 \\
334\end{array}$ & $\begin{array}{l}330 \\
303 \\
\frac{362}{332}\end{array}$ \\
\hline \multirow[t]{2}{*}{ B $1-1-4$} & 3 & $\begin{array}{l}\text { Inside Edge } \\
\text { Center } \\
\text { Outside Edge } \\
\text { Average }\end{array}$ & $\begin{array}{l}321 \\
294 \\
303 \\
306\end{array}$ & $\begin{array}{l}341 \\
330 \\
341 \\
337\end{array}$ & $\begin{array}{l}362 \\
341 \\
330 \\
344\end{array}$ \\
\hline & 6 & $\begin{array}{l}\text { Inside Edge } \\
\text { Center } \\
\text { Outside Edge } \\
\text { Average }\end{array}$ & $\begin{array}{l}341 \\
321 \\
351 \\
338\end{array}$ & $\begin{array}{l}351 \\
303 \\
341 \\
332\end{array}$ & $\begin{array}{l}412 \\
362 \\
\frac{399}{391} \mathrm{a}\end{array}$ \\
\hline \multicolumn{6}{|c|}{$\begin{array}{l}{ }^{a} \text { SPA } 790430 \text {, paragraph } 3.2 .1 \text {, Hardness: "Microhardness of the fully } \\
\text { processed cup shall be between } 250 \text { and } 350 \text { DPH." }\end{array}$} \\
\hline
\end{tabular}

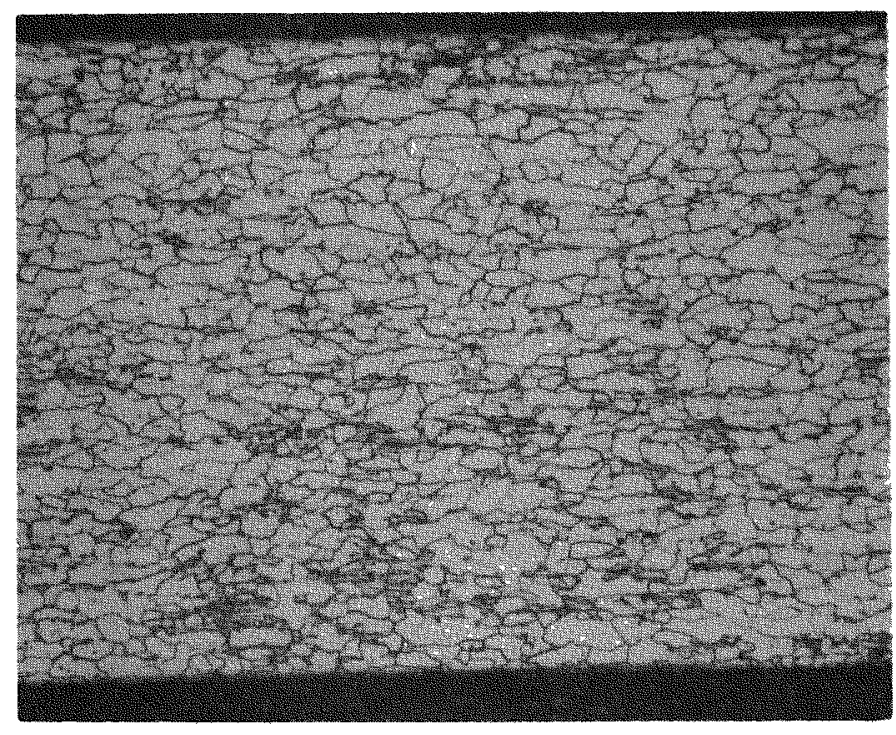

FIGURE 8 - Iridium cup B1-1-4 (100X). Improved/ not outgassed bottom section. The elimination of the $1500^{\circ} \mathrm{C}$ outgassing operation produced iridium cups that displayed some unrecrystallized grain structure. 
material, or delaminations were present. Therefore, all material specification requirements, except for microhardness, were met.

\section{EB Welding Evaluations}

The new improved B-batch iridium material was evaluated for weldability by the EB process. Six development GPHS iridium cups had decon covers, frit vents, and weld shields EB-welded onto them. Four of the six cups were outgassed prior to welding using the normal GPHs outgassing procedure. The EB welding parameters used were the same as those used on GPHS iridium cup production. The welds all looked normal during visual examination.

Two outgassed decon cover and frit vent assembly welds were cross-sectioned and metallographically evaluated (Figures 9 and 10). The grain structure of the welds demonstrated an acceptable mixture of columnar and small, irregular grains. This grain structure is not expected to contribute to weld cracking and should exhibit excellent weld strength. The grain size in the weld area was comparable to the grain size of EB welds on GPHS production iridium welds. There was no evidence of cracking. The other two cups from the outgassed material were dye-penetrant checked and showed no evidence of surface cracks.

The remaining two cups were not outgassed by the GPHS production process. They were EB-welded with test results comparable to those of the outgassed material. Figure 11 shows the cross section of one of the frit vent and decon cover welds. The other nonoutgassed cup was dyepenetrant checked and showed no evidence of cracks.

\section{Observations and Recommendations}

1. OBSERVATION - The larger-than-design wall thickness in the weld zone and wall thickness variation within each iridium cup will present weldability problems at SRP.

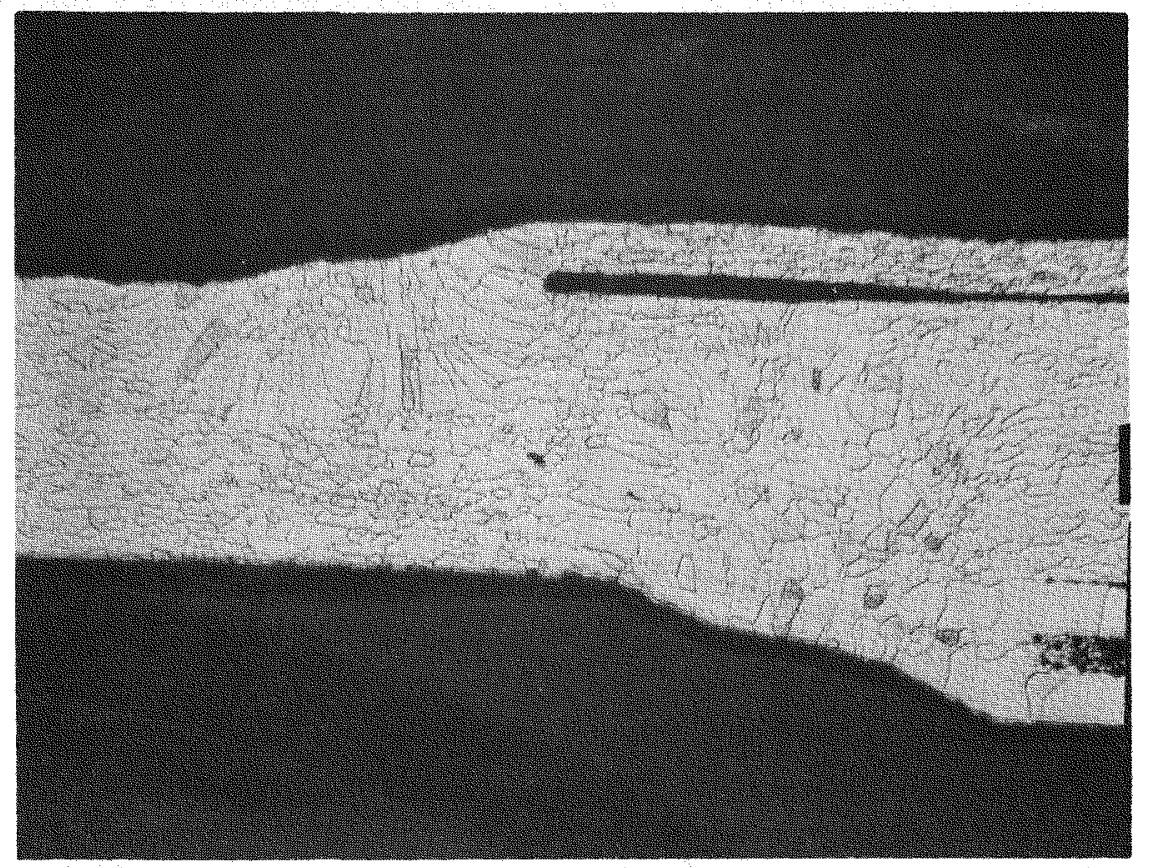

FIGURE 9 - Cross section of iridium cup B2-1-1 showing $E B$ weld of the decon cover and frit vent assembly. This cup was outgassed. (45X) 


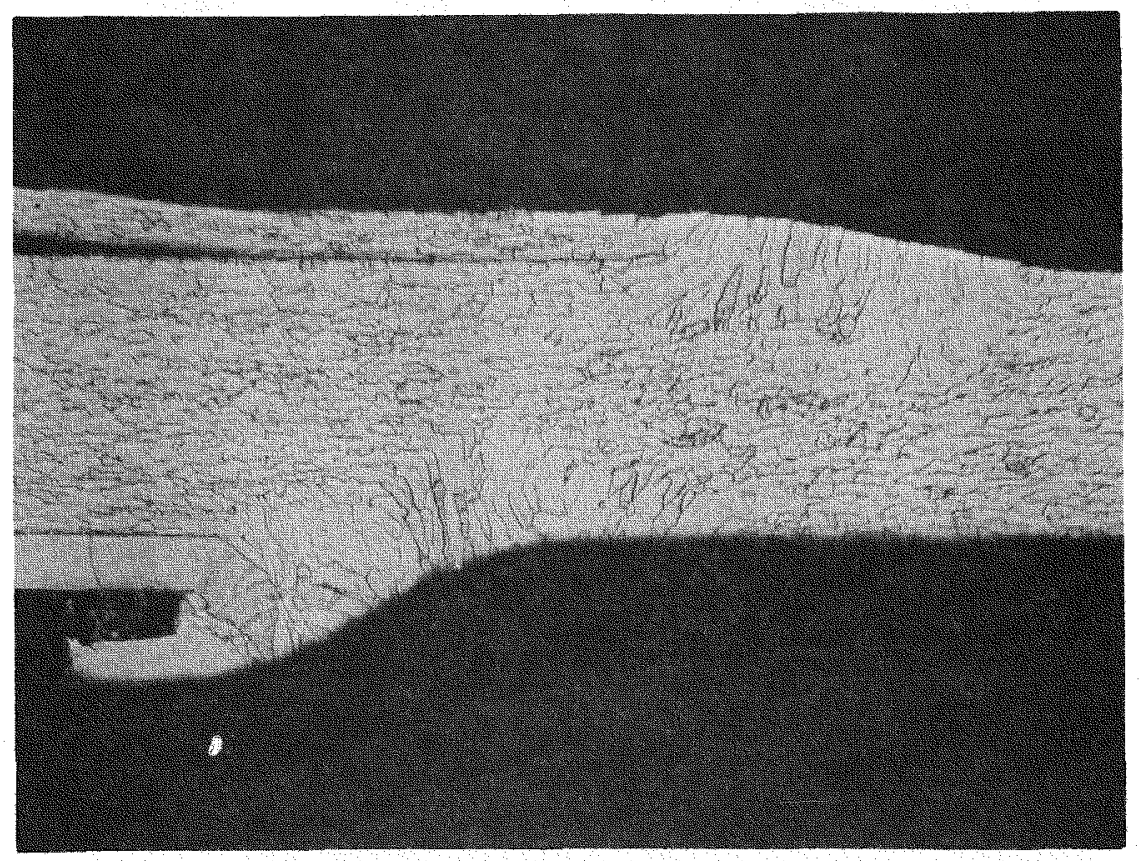

FIGURE 10 - Cross section of iridium cup B2-5-2 showing EB weld of the decon cover and frit vent assembly. This cup was outgassed. $(45 X)$

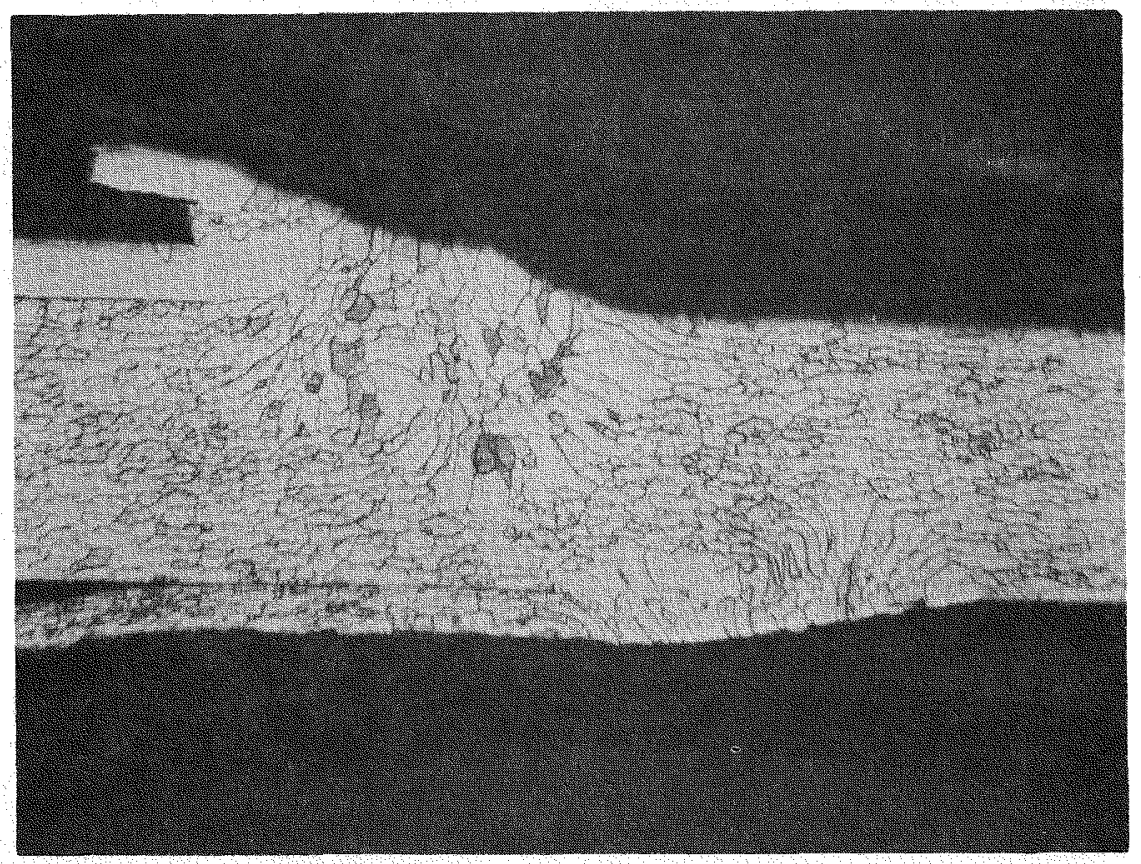

FIGURE 11 - Cross section of iridium cup B2-5-5 showing EB weld of the decon cover and frit vent assembly. This cup was not outgassed. $(45 X)$ 
RECOMMENDATION - If this condition cannot be resolved by additional developmental forming studies, Mound can implement a mechanical grinding procedure to control wall thickness size and variation within the 100-mil weld zone. (A similar technique was used in the latter stages of Mound's multi-hundred watt hemi-shell production run.)

2. OBSERVATION - The archive ring segment removed from $B$-batch materials was considerably shorter than segments from GPHS production units. Therefore, blank alignment during Mound's warm-forming operations will be more critical than was previously realized. Also, this condition is believed to have contributed to the thicker weld zone and variation in wall thickness in the formed iridium cups.

RECOMMFNDATION - ORNL should consider fabricating improved-iridium blanks with a larger diameter. Mound should evaluate the warm-forming operations to improve part alignment during forming procedures. Also, stressrelieving temperature parameters should be evaluated via a temperature matrix forming study.

3. OBSERVATION - TwO of the 34 iridium cups experienced sidewall cracks resulting from oRNL's identity notches ground in the iridium blank circumference. A $5.9 \%$ rejection rate can be projected for additional CVS production based on Mound's rejection rate for lots $\mathrm{P}-30$ through $\mathrm{P}-50$.
RECOMMENDATION - ORNL should considex alternate methods, such as lasermarking or mechanical scribing, to identify rolling direction and individual parts.

4. OBSERVATION - The improved iridium did not meet microhardness requirements when subjected to the $1500^{\circ} \mathrm{C}$ outgassing temperature and was not fully recrystallized at the $1300^{\circ} \mathrm{C}$ recrystallization temperature.

RECOMMENDATION - Mound and ORNL need to establish a recrystallization temperature for improved iridium. Also, the new recrystallization parametex must adaress microhardness concerns.

5. OBSERVATION - The preliminary look at $\mathrm{EB}$ welding characteristics showed no indications of CVS manufacturing problems with ORNL's proposed fabrication process or Mound's suggestion to change the final outgassing temperature to $1000^{\circ} \mathrm{C}$. Phase II objectives using both improved-iridium blanks and foil will be more conclusive.

RECOMMENDATION - The final outgassing temperature should be changed to $600^{\circ} \mathrm{C}$. This parameter is well below the recrystallization temperature and will assure product cleanliness for subsequent $\mathrm{EB}$ welding operations.

\section{Conclusions}

Mound's formability study was primarily designed to identify any processing problems associated with improved iridium. The Cvs wall thickness variation is 
considered to be the only significant problem in meeting product specification requirements. This anomaly can be corrected by the mechanical grinding technique previously developed for the multi-hundred watt program. However, additional forming studies would permit evaluations of a larger blank size, more accurate alignment during warm-forming, stress relieving before forming, etc.

Because neither population of iridium cups experienced delaminations in the lapped surfaces, the formability study is considered to be inconclusive in this regard. Also, the lack of delaminations cannot be solely attributed to B-batch iridium powder, since Mound's production lots $\mathrm{P}-31, \mathrm{P}-33, \mathrm{P}-35$, and $\mathrm{P}-44$ were processed with no delaminations occurring. Overall, the dye-penetrant acceptance rate was excellent. The as-formed cups were acceptable without mechanical polishing, no delaminations were observed, and the two "cracked" cups resulted from identity notches, not base materials.
The data generated to date strongly support the continuation of ORNL's development plan. Based on a relatively small sample size, the ultrasonic and dye-penetrant acceptance indicate a aramatic improvement in ORNL's and Mound's processing yields. Because additional iridium CVS will be required to support phase II and phase III of ORNL's study, Mound suggests the recommended changes defined in this document be further evaluated during these phases of the study.

\section{Acknowledgements}

The authors wish to acknowledge Dr. E. W. Johnson for his technical expertise relating to iridium formability and also for his guidance and support toward this endeavor.

We also wish to thank D. A. Sohn of the Metallography section for his preparation and interpretation of specimens. 


\section{Distribution}

EXTERNAL

TIC, UC-25 (177)

W. J. Barnett, DOE/DSA

S. E. Bronisz, Los Alamos National Laboratory

J. T. Buckner, Savannah River Plant

T. G. George, Los Alamos National Laboratory

R. L. Heestand, Oak Ridge National Laboratory

E. E. Hoffman, DOE/ORO

W. R. Kanne, Savannah River Plant

M. M. Martin, Oak Ridge National Laboratory

J. A. Morley, DOE/DAO

M. A. Reker, DOE/DAO

T. K. Roche, Oak Ridge National Laboratory

H. A. Schneiderman, Monsanto, St. Louis

Monsanto Reports Library, R2C, St. Louis

\section{INTERNAL}
W. R. Amos
II. F. Anderson
W. A. Bohne
M. A. Forrest
D. M. Gabriel
K. C. Good
W. B. Hogeman
C. W. Huntington
E. W. Johnson
J. R. MCDougal
R. W. Saylor
W. H. Smith
R. E. Vallee
Publications
Library (15) 